Prosiding Seminar Nasional Teknologi Informasi dan Kedirgantaraan : Transformasi Teknologi untuk Mendukung Ketahanan Nasional, Yogyakarta, 13 Desember 2018

SENATIK 2018, Vol. IV, ISBN 978-602-52742-0-6

DOI: http://dx.doi.org/10.28989/senatik.v4i0.138

\title{
USE OF LIPAT ALGORITHM ON ANDROID TO SECURE DATA COMMUNICATION IN SOCIAL MEDIA Hero Wintolo ${ }^{1)}$, Asih Pujiastuti' ${ }^{2)}$, Muhammad Imam ${ }^{3)}$ \\ ${ }_{1,2,3}$ Program Studi Informatika \\ Sekolah Tinggi Teknologi Adisutjipto \\ Jl. Janti, Blok-R, Lanud Adisucipto Yogyakarta \\ Corresponding author email : imam211096@gmail.com
}

\begin{abstract}
Cryptography is one of science that learn about securing a message. Message security is done by randomizing the message (encryption) and returned to it's original form (description). In this study, the designer of the system first and build an application to secure the message by using the Lipat Algorithm method that aims to secure messages consisting of letters, numbers, or symbols. Applications are designed and built running on Mobile Android. The Lipat Algorithm Method applies a fourfold system in the encryption process and the description of the message to be encrypted and in the description will advance 4 (four) characters forward or backward. Based on testing done the application managed to perform the encryption process and description correctly, ranging from short messages to messages as much as 2305 characters.
\end{abstract}

Keywords: Cryptography, Lipat Algorithm, Android Mobile App

Abstrak

Kriptografi adalah salah satu ilmu yang yang mempelajari tentang pengamanan sebuah pesan. Pengamanan pesan dilakukan dengan cara mengacak pesan (enkripsi) dan dikembalikan lagi kebentuk aslinya (deskripsi). Pada penelitian ini, terlebih dahulu dilakukan perancang sistem dan membangun sebuah aplikasi untuk mengamankan pesan dengan menggunakan metode Algoritma Lipat yang bertujuan untuk mengamankan pesan yang terdiri dari huruf, angka, atau simbol. Aplikasi yang dirancang dan dibangun berjalan di Mobile Android. Metode Algoritma Lipat menerapkan sistem kelipatan empat dalam proses enkripsi dan deskripsi yaitu pesan yang akan di enkripsi dan di deskripsi akan dimajukan 4 (empat) karakter kedepan atau kebelakang. Berdasarkan pengujian yang dilakukan aplikasi berhasil melakukan proses enkripsi dan deskripsi dengan benar, mulai dari pesan singkat sampai dengan pesan sebanyak 2305 karakter.

Kata kunci : Kriptografi, Algoritma Lipat, Aplikasi Mobile Android

\section{Pendahuluan}

Komunikasi berasal dari bahasa latin communicatio yang berarti pemberitahuan atau pertukaran pikiran. Secara umum dalam suatu proses komunikasi haruslah terdapat unsurunsur kesamaan, maka agar terjadi suatu pertukaran pikiran dan pengertian antara communicator (penyebar pesan) dan communicant (penerima pesan). Proses komunikasi dapat diartikan sebagai transfer informasi atau pesan (message) dari pengirim pesan kepada penerima. Salah satu ilmu yang mempelajari tentang pengamanan pengiriman pesan adalah Kriptografi, yang berfungsi untuk mengamankan pesan yang dikirimkan sehingga pesan tersebut tetap aman walaupun disadap, dicuri atau dibajak.

Penggunaan kriptografi dalam sebuah aplikasi yang dapat dijalankan pada peralatan 
telekomunikasi dengan sistem operasi android dapat berupa catatan atau diari[1], dan pesan atau message mengunakan text base application. Untuk membuat aman sebuah pesan yang akan dikirimkan dan diterima, dibutuhkan algoritma kriptografi. Bahkan untuk membuat sebuah pesan menjadi aman, ada yang menerapkan empat algoritma kriptografi sekaligus[2] dalam sebuah aplikasi yang berjalan pada android. Selain itu, untuk membuat pesan menjadi aman, pesan tersebut diberi kunci public dan private sebelum dan setelah dikirimkan. Dengan memadukan kunci publik dengan metode playfair chiper dimana pada kunci publik yang diatur diubah terlebih dahulu atau di enkripsi dengan playfair chiper baru bisa dipecahkan kembali dengan algoritma Rivest Shamir Adleman (RSA)[3]. Selain RSA, ada beberapa algoritma yang dapat digunakan untuk mengamankan sebuah pesan yang dikirimkan, salah satunya RC6[4]. Selain untuk pesan, algoritma RSA juga dapat digunakan dalam aplikasi chatting [5] yang tidak dapat dibaca oleh perangkat lunak wire shark.

Metode untuk mengenkripsi teks pesan menjadi pesan rahasia yang kemudian hasilnya diteruskan sebagai teks pesan ke aplikasi pengiriman pesan seperti aplikasi SMS (Short Message Service), Whatsapp, Line, dan sejenisnya untuk selanjutnya di dekripsi pada aplikasi berbasis android yang dapat mengirimkan teks pesan terenkripsi menggunakan metode Vigenere Cipher untuk memberikan keamanan lebih pada proses pertukaran informasi[6]. Untuk tingkat keamanan dari algoritma Vigenere Cipher yang telah dimodifikasi lebih aman dibandingkan dengan algoritma Vigenere Cipher standar karena panjang kunci yang dihasilkan lebih panjang dan cipher text lebih acak sehingga sulit dipecahkan oleh kriptanalis[7]. Selain untuk pesan dan chatting, kriptografi juga dapat digunakan untuk mengamanan proses sinkronisasi file[8], sehingga tingkat keamanan saat file sampai di komputer tujuan lebih terjamin.

Jumlah perangkat android dan pengguna internet di Indonesia membuat budaya komunikasi pesan yang dahulu menggunakan SMS kini telah berkembang dengan beberapa perangkat lunak dari berbagai macam vendor. Keterbatasan yang ada pada SMS telah ditutupi oleh perangkat lunak untuk komunikasi bebrbasis teks saat ini. Hanya masalah keamanan yang perlunya untuk diperhatikan dan dikembangkan. Dengan menggunakan kriptografi yang menerapkan beberapa metode yang sudah ada, misalnya Serpent [9], atau metode yang dibuat sendiri yang digunakan dalam membuat aplikasi pada artikel ini, yaitu lipat[10], diharapkan tingkat keamanan dalam komunikasi berbasis teks ini lebih terjamin.

Algoritma Lipat yaitu algoritma yang digunakan untuk menyisipkan pesan kedalam data (gambar) kedalam bit yang paling akhir dengan menggunakan rumus increment_PANJANG_PESAN \% 4!=0'. Pada perkembangannya dalam penelitian dan pembangunan aplikasi ini akan mencoba mengembangkan metode tersebut untuk mengamankan data berupa pesan teks yang akan diacak menggunakan rumus yang telah dimodifikasi dari yang mulanya 'increment-_PANJANG_PESAN \% 4!=0' menjadi 'PANJANG_PESAN \% 2!=0' yang menjadi panjang pesan adalah nilai decimal atau kode ASCII dari setiap karakter yang di input kedalam pesan yang akan dikirim, sehingga setiap kode decimal akan dibagi 2 dan apabila hasilnya 0 (genap) maka karakter tersebut akan maju 4 (empat) karakter kedepannya, dan apabila hasilnya 1 (ganjil) maka karakter tersebut akan mundur 4 (empat) karakter kebelakang.

Sebagai contoh jika user mengimputkan karakter A maka kode ASCII nya adalah 65 maka 65\%2=1 maka akan dimundurkan 4 (empat) karakter kebelakang menjadi kode ASCII 61 yaitu karakter $=($ sama dengan $)$. Begitupun jika user mengimputkan karakter $\mathrm{N}$ maka kode ASCII nya adalah 78 maka 78\%2=0 maka akan dimajukan 4 (empat) karakter kedepan menjadi kode ASCII 82 yaitu karakter R. Sehingga nantinya akan mengacak pesan tersebut yang berupa huruf, angka, dan simbol yang terdapat pada kode ASCII mulai dari 32 sampai 127. Apabila pesan tersebut sudah diacak maka akan dikembalikan dalam bentuk semula oleh si penerima pesan. 


\section{Metodologi Penelitian}

\subsection{Diagram Alir Perangkat Lunak}

Perancangan diagram alir perangkat lunak untuk melakukan proses enkripsi dan deskripsi dimulai dari pengguna (user) baik pengirim dan penerima pesan terlebih dahulu melakukan proses intalisasi aplikasi sehingga aplikasi tersebut dapat berjalan dengan baik di smartphone android mereka. Selanjutnya pengirim mengetik pesan yang akan di enkripsi kedalam aplikasi sehingga nantinya memperoleh pesan yang telah di enkripsi. Sehingga pesan tersebut dikirim kepada pihak penerima yang nantinya akan mengembalikan pesan tersebut kebentuk aslinya supaya bisa dibaca dan dipahami. Hasil perancangan diagram alir dapat dilihat pada Gambar 1.

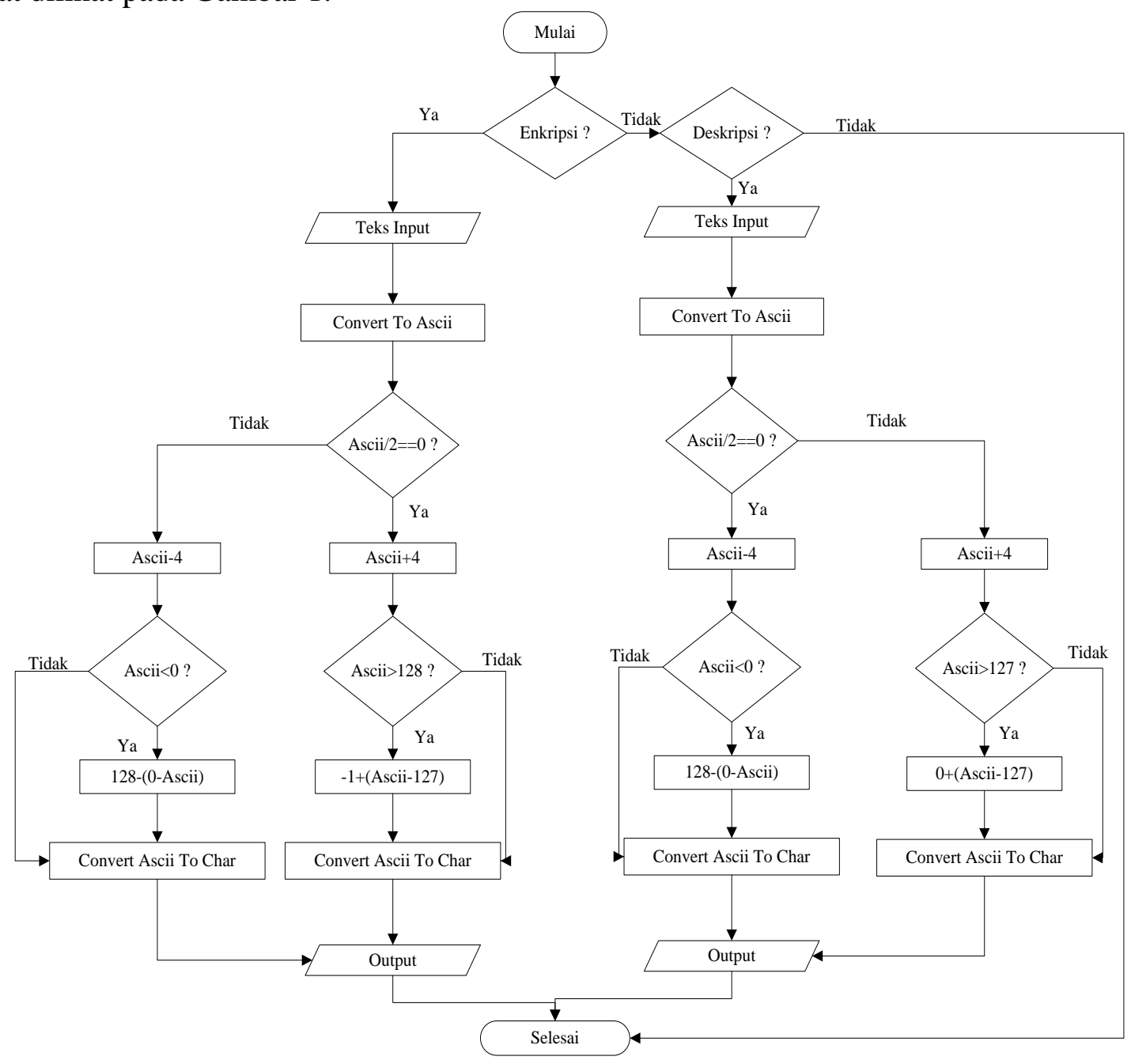

Gambar 1 diagram alir perangkat lunak

\subsection{Use Case Diagram}

Pada aplikasi yang dibangun ini pembuatan Use Case Diagram bertujuan untuk menjelaskan secara singkat proses apa saja yang bisa dilakukan oleh pengguna (user) terhadap sistem adalah Input Teks, Kemudian melakukan proses Enkripsi atau Deskripsi dan 
memperoleh hasil dari proses Enkripsi dan Deskripsi. Hasil rancangan Use Case Diagram dapat dilihat pada Gambar 2.

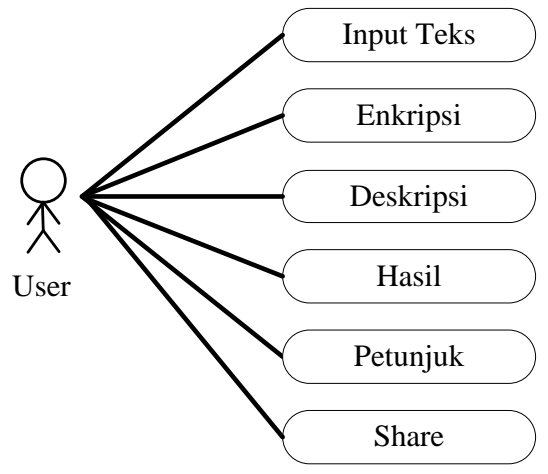

Gambar 2. Usecase Pengguna

\subsection{Activity Diagram}

Activity Diagram aplikasi yang dirancang menjelaskan alur atau proses pada aplikasi tersebut, alur penggunaan pada aplikasi dimulai saat pengguna memilih untuk melakukan proses enkripsi atau deskripsi, setelah memilih maka pengguna melakukan input teks yang akan diproses oleh sistem, sehingga akan memperoleh hasil enkripsi atau deskripsi dari teks yang di input. Hasil dari perancangan Activity Diagram dapat dilihat pada Gambar 3.

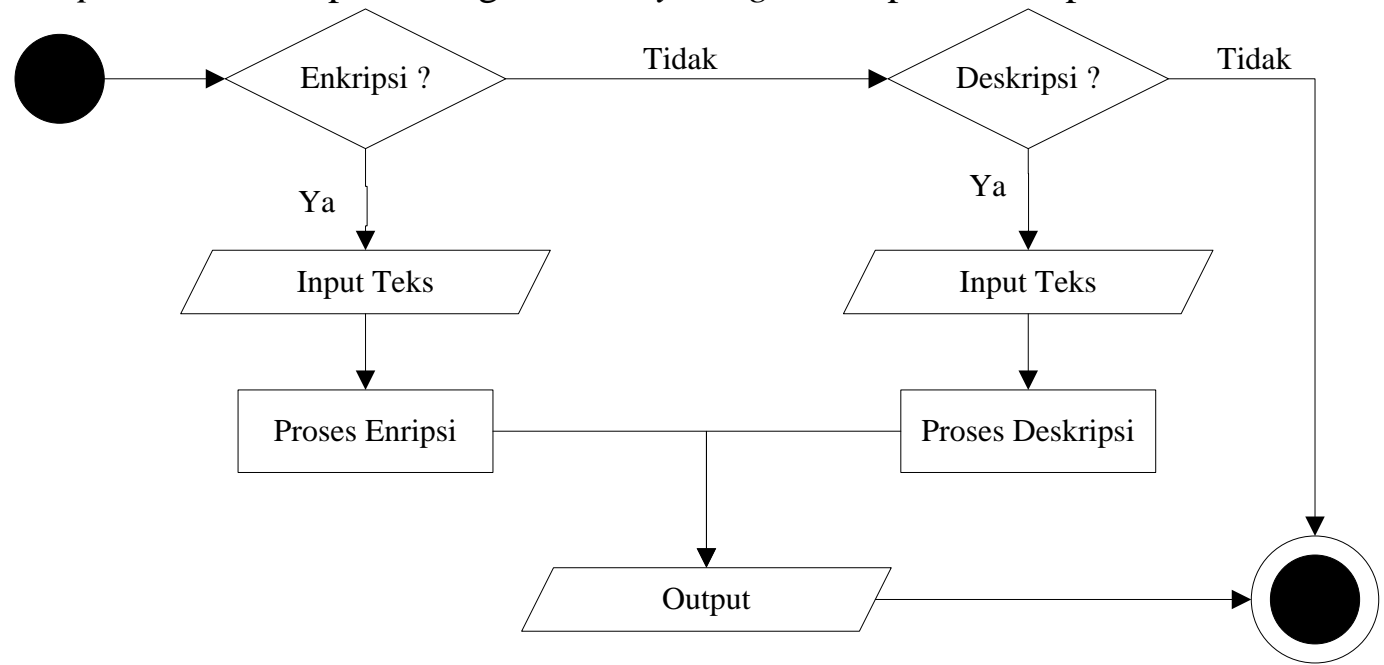

Gambar 3. Activity Diagram

\section{Pengujian dan Pembahasan}

\subsection{Pengujian Semua Karakter}

Sebelum melakukan pengujian untuk semua karakter yang dimulai dari kode ASCII 0 sampai 127 terlebih dahulu penulis melakukcan penghitungan secara manual dengan rumus 'PANJANG_PESAN\%2!=0' sehingga diperoleh hasil seperti Tabel 1. 
Tabel 1. Contoh Hasil Perhitungan Manual

\begin{tabular}{|c|c|c|c|}
\hline Kode ASCII & Karakter & Enkripsi & Deskripsi \\
\hline 0 & NUL & EOT & NUL \\
\hline 1 & SOH & \} & SOH \\
\hline 2 & STX & ACK & ATX \\
\hline 3 & ETX & DEL & ETX \\
\hline 4 & EOT & BS & EOT \\
\hline 5 & ENQ & SOH & ENQ \\
\hline$\ldots$ & $\ldots$ & $\ldots$ & $\ldots$ \\
123 & \{ & W & \{ \\
\hline 124 & \{ & NUL & \} \\
\hline 125 & $\sim$ & STX & $\sim$ \\
\hline 126 & DEL & \{ & DEL \\
\hline 127 & & & \\
\hline
\end{tabular}

Keterangan Kode-kode di atas adalah sebagai berikut:

0. NUL=Null Char

1. $\mathrm{SOH}=$ Star of Header

2. STX=Star of Text

3. ETX=End of Text

4. $\mathrm{EOT}=$ End of Transmission

5. $\mathrm{ENQ}=$ Enquiry

Dari hasil perhitungan manual seperti pada Tabel 1 maka akan dilakukan proses pengujian enkripsi dan deskripsi pada sistem aplikasi apakah sesuai dengan hasil perhitungan manual atau tidak. Uji fungsi enkripsi adalah proses pengujian enkripsi atau mengacak pesan yang diketik oleh user yang terdiri dari huruf, angka, simbol. Hasil dari proses enkripsi dapat dilihat pada gambar 4 .

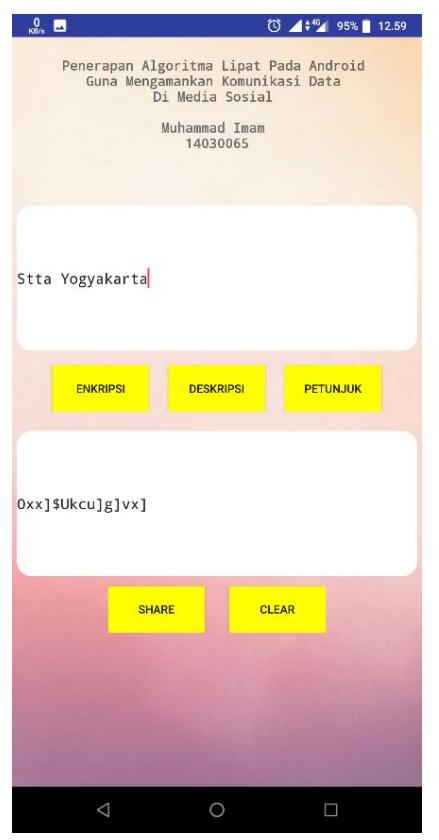

Gambar 4. Proses Enkripsi 
Uji fungsi deskripsi adalah proses pengujian Deskripsi atau Mengembalikan pesan kebentuk aslinya, sehingga pesan yang tadinya di Enkripsi atau di Acak dapat dikembalikan kebentuk aslinya sehingga dapat dipahami. Hasil dari uji fungsi deskripsi dapat dilihat pada Gambar 5.

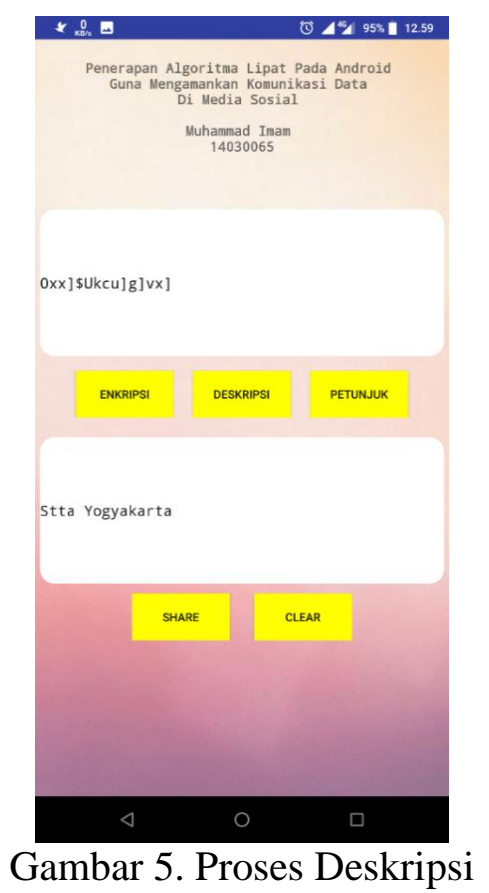

\subsection{Pengujian Pesan Singkat}

Proses pengujian dengan melakukan proses enkripsi dan deskripsi pada pesan singkat bertujuan untuk mengetahui apakah sistem sudah bisa melakukan proses dengan benar atau tidak. Pada proses pengujiannya dengan melakukan proses enkripsi dan deskripsi pesan singkat menghasilkan output dari proses enkripsi dan dikembalikan kebentuk aslinya melalui proses deskripsi yang mana hasil dari proses deskripsi persis sama dengan teks aslinya, jadi bisa disimpulkan bahwa proses enkripsi dan dekripsi pesan singkat berhasil dilakukan dengan benar oleh sistem. Hasil dari proses pengujian pesan singkat dapat dilihat pada Tabel 2.

Tabel 2. Proses Enkripsi dan Deskripsi Pesan Singkat

\begin{tabular}{|c|c|c|}
\hline Teks Asli & Hasil Enkripsi & Hasil Deskripsi \\
\hline $\begin{array}{l}\text { Mengingatkan kembali } \\
\text { Bahwa mahasiswa yg } \\
\text { mengambil makul mobile } \\
\text { computing kls b besok pagi } \\
\text { bahwa tugas dikumpul ke baak } \\
\text { paling lambat pkl 14.00. } \\
\text { Terima Kasih }\end{array}$ & $\begin{array}{l}\text { Iarcerc]xg]r\$gaif]peF]ls]\$ } \\
\text { i]l]oeos]\$uc\$iarc]ifep\$i]g } \\
\text { qp\$ikfepa\$_kitqxerc\$gpo } \\
\text { \$f\$faokg\$t]ce\$f]ls]\$xqc]o } \\
\text { \$hegqitqp\$ga\$f]]g\$t]perc } \\
\text { \$p]if]x\$tgp\$- } \\
\text { 82442Xavei]\$G]oel }\end{array}$ & $\begin{array}{l}\text { Mengingatkan kembali } \\
\text { Bahwa mahasiswa yg } \\
\text { mengambil makul mobile } \\
\text { computing kls b besok pagi } \\
\text { bahwa tugas dikumpul ke } \\
\text { baak paling lambat pkl } \\
14.00 . \\
\text { Terima Kasih }\end{array}$ \\
\hline
\end{tabular}

\subsection{Pengujian Berita}

Pada tahapan pengujian ini sistem akan mencoba mencoba menguji sebuah berita yang dikutip dari website https://stta.ac.id/stta/portal/blog/detail/74/stta-menjalin-kerjasama- 
dengan-pt-yasunli-abadi-utama-plastik diakses pada hari Senin, 14 Mei 2018 jam 11.11. Pada tahapan dilakukan proses Enripsi dan Deskripsi dengan jumlah karakter 2.305. Proses pengujian berita dapat dilihat pada Tabel 3 .

Tabel 3. Pengujian Proses Enkripsi dan Deskripsi Berita

\begin{tabular}{|c|c|c|}
\hline sli & Hasil Enkripsi & ipsi \\
\hline $\begin{array}{l}\text { Pada hari senin, tanggal } 23 \\
\text { April } 2018 \text { Sekolah Tinggi } \\
\text { Teknologi } \\
\text { (STTA) telah Adisutjipto } \\
\text { kerjasama dengan PT. Yasunli } \\
\text { Abadi Utama }\end{array}$ & $\begin{array}{l}\text { T]h]\$1]ve\$oarer0\$x]rcc]p } \\
\$ 6 / \$=\text { tvep\$64- } \\
<\$ \text { Oagkp]l\$Xercee\$Xagrk } \\
\text { pkce\$=heoqxnetxk\$, } \\
\text { OXX=\%\$xap]1\$iaverxeo\$ } \\
\text { gavn]o]i]\$harc]r\$TX2\$U] }\end{array}$ & $\begin{array}{l}\text { Pada hari senin, tanggal } 23 \\
\text { April 2018 Sekolah Tinggi } \\
\text { Teknologi } \\
\text { (STTA) telah merisutipto } \\
\text { kerjasama dengan PT. } \\
\text { Yasunli Abadi Utama }\end{array}$ \\
\hline $\begin{array}{lr}\text { Plastik. } & \text { Penandatangan } \\
\text { Perjanjian Kerjasama tersebut } \\
\text { dilakukan di Factory III PT. } \\
\text { Yasunli abadi Utama Plastik } \\
\text { yang beralamat di Jl. Flores } \\
\text { Blok C1 No: 3-6 Kws Industri } \\
\text { MM2100 Ckarang Barat } \\
\text { Bekasi. Dengan adanya } \\
\text { perjanjian kerjasama ini } \\
\text { diharapkan STTA dan PT. } \\
\text { Yasunli Abadi Utama Plastik } \\
\text { dapat bekerjasama dalam hal } \\
\text { Tridharma pendidikan } \\
\text { Perguruan tinggi yang } \\
\text { meliputi pendidikan, } \\
\text { penelitian, pelatihan, praktik } \\
\text { kerja, dan magang serta } \\
\text { recruitment untuk alumni- } \\
\text { alumni STTA. PT. Yasunli } \\
\text { Abadi Utama Plastik sendiri } \\
\text { merupakan suatu perusahaan } \\
\text { yang awalnya berspesialisasi } \\
\text { dalam memproduksi }\end{array}$ & $\begin{array}{l}\text { oqrpe\$=f]he\$Qx]i]\$Tp]ox } \\
\text { eg2\$Tar]rh]x]rc]r\$Tavn]r } \\
\text { ne]r\$Gavn]o]i]\$xavoafqx } \\
\text { \$hep]gqg]r\$he\$J]xkvu\$E } \\
\text { EE\$TX2\$U]oqrpe\$]f]he\$ } \\
\text { Qx]i]\$Tp]oxeg\$u]rc\$fav] } \\
\text { p]i]x\$he\$Np2\$Jpkvao\$Fp } \\
\text { kg\$?- } \\
\text { \$Rk>\$/):Gso\$Erhqoxve\$ } \\
\text { II6- } \\
\text { 44\$?]v]rc\$F]v]x\$Fag]oe } \\
\text { 2\$Harc]r\$]h]ru]\$tavn]rne] } \\
\text { r\$gavn]o]i]\$ere\$hel]v]tg]r } \\
\text { \$OXX=\$h]r\$TX2\$U]oqrp } \\
\text { e\$=f]he\$Qx]i]\$Tp]oxeg\$h } \\
\text { ]t]x\$fagavn]o]i]\$h]p]i\$l]p } \\
\text { \$Xvehl]vi]\$tarheheg]r\$Ta } \\
\text { vcqvq]r\$xercce\$u]rc\$iape } \\
\text { tqxe\$tarheheg]r0\$tarapexe } \\
\text { ]r0\$tap]xel]r0\$tv]gxeg\$ga } \\
\text { vn]0\$h]r\$i]c]rc\$oavx]\$va } \\
\text { _vqexiarx\$qrxqg\$]pqire)] } \\
\text { pqire\$OXX=2\$TX2\$U]oq } \\
\text { rpe\$= } \\
\text { f]he\$Qx]i]\$Tp]oxeg\$oarh } \\
\text { eve\$iavqt]g]r\$ }\end{array}$ & $\begin{array}{l}\text { Plastik. Penandatangan } \\
\text { Perjanjian Kerjasama } \\
\text { tersebut dilakukan di Factory } \\
\text { III PT. Yasunli abadi Utama } \\
\text { Plastik yang beralamat di Jl. } \\
\text { Flores Blok C1 No: 3-6 Kws } \\
\text { Industri MM2100 Ckarang } \\
\text { Barat Bekasi. Dengan adanya } \\
\text { perjanjian kerjasama ini } \\
\text { diharapkan STTA dan PT. } \\
\text { Yasunli Abadi Utama Plastik } \\
\text { dapat bekerjasama dalam hal } \\
\text { Tridharma pendidikan } \\
\text { Perguruan tinggi yang } \\
\text { meliputi pendidikan, } \\
\text { penelitian, pelatihan, praktik } \\
\text { kerja, dan magang serta } \\
\text { recruitment untuk alumni- } \\
\text { alumni STTA. PT. Yasunli } \\
\text { Abadi Utama Plastik sendiri } \\
\text { merupakan suatu perusahaan } \\
\text { yang awalnya berspesialisasi } \\
\text { dalam memproduksi }\end{array}$ \\
\hline
\end{tabular}

Proses pengujian dengan melakukan proses enkripsi dan deskripsi pada sebuah berita bertujuan untuk mengetahui apakah sistem sudah bisa melakukan proses enkripsi dan deskripsi dengan benar atau tidak, dipilihnya pengujian menggunakan berita bertujuan untuk apakah sistem mampu melakukan proses enkripsi dan deskripsi dengan banyak karakter sampai 2305 karakter. Pada proses pengujiannya dengan melakukan proses enkripsi dan deskripsi berita menghasilkan output dari proses enkripsi dan dikembalikan kebentuk aslinya melalui proses deskripsi yang mana hasil dari proses deskripsi persis sama dengan teks 
aslinya, jadi bisa disimpulkan bahwa proses enkripsi dan dekripsi berita Berhasil dilakukan dengan benar oleh sistem. Hasil dari proses pengujian berita dapat dilihat pada Tabel 3.

\subsection{Pembahasan}

Aplikasi Android Penerapan Algoritma Lipat Pada Android Guna Mengamankan Komunikasi Data Di Media Sosial adalah sebuah aplikasi sederhana yang bertujuan untuk mengacak huruf, angka, simbol sehingga tidak bisa dipahami oleh pihak yang tidak berkepentingan. Sebagai contoh, user mengacak sebuah kata yaitu Sekolah maka hasilnya setelah diacak (enkripsi) adalah Oagkp]l maka untuk dikembalikan kebentuk aslinya menggunakan proses deskripsi sehingga pesan yang tadi diacak dapat dikembalikan kebentuk aslinya yaitu Sekolah. Proses Enkripsi pada sistem di aplikasi menggunakan metode Algoritma Lipat (Kelipatan Empat). Seperti pesan tadi yang awalnya Sekolah maka bisa berubah menjadi Oagkp]l untuk lebih jelas proses enkripsinya dapat dilihat pada Tabel 4.

Tabel 4. Proses Enkripsi

\begin{tabular}{|c|l|}
\hline Karakter & \multicolumn{1}{|c|}{ Proses Enkripsi } \\
\hline $\mathrm{S}$ & $\begin{array}{l}\text { Karakter S diubah menjadi ASCII yaitu 83 kemudian dibagi 2, maka } \\
\text { hasilnya lebih 1 (gajil) maka 83-4=79 kemudian hasil pengurangannya } \\
\text { diubah menjadi karakter yaitu karakter O }\end{array}$ \\
\hline $\mathrm{e}$ & $\begin{array}{l}\text { Karakter e diubah menjadi ASCII yaitu 101 kemudian dibagi 2, jika } \\
\text { hasilnya lebih 1 (gajil) maka 101-4=97 kemudian hasil pengurangannya } \\
\text { diubah menjadi karakter yaitu karakter a }\end{array}$ \\
\hline $\mathrm{K}$ & $\begin{array}{l}\text { Karakter k diubah menjadi ASCII yaitu 107 kemudian dibagi 2, maka } \\
\text { hasilnya lebih 1 (gajil) maka 107-4=103 kemudian hasil pengurangannya } \\
\text { diubah menjadi karakter yaitu karakter g }\end{array}$ \\
\hline $\mathrm{O}$ & $\begin{array}{l}\text { Karakter o diubah menjadi ASCII yaitu 111 kemudian dibagi 2, maka } \\
\text { hasilnya lebih 1 (gajil) maka 111-4=107 kemudian hasil pengurangannya } \\
\text { diubah menjadi karakter yaitu karakter k }\end{array}$ \\
\hline 1 & $\begin{array}{l}\text { Karakter l diubah menjadi ASCII yaitu 108 kemudian dibagi 2, maka } \\
\text { hasilnya 0 (genap) maka 108+4=112 kemudian hasil penjumlahannya } \\
\text { diubah menjadi karakter yaitu karakter p }\end{array}$ \\
\hline $\mathrm{a}$ & $\begin{array}{l}\text { Karakter a diubah menjadi ASCII yaitu 97 kemudian dibagi 2, maka } \\
\text { hasilnya lebih 1 (gajil) maka 97-4=93 kemudian hasil pengurangannya } \\
\text { diubah menjadi karakter yaitu karakter ] }\end{array}$ \\
\hline $\begin{array}{l}\text { Karakter h diubah menjadi ASCII yaitu 104 kemudian dibagi 2, maka } \\
\text { hasilnya 0 (genap) maka 104+4=108 kemudian hasil penjumlahannya } \\
\text { diubah menjadi karakter yaitu karakter l }\end{array}$ \\
\hline h
\end{tabular}

Pada proses Deskripsi dilakukan kebalikan dari proses Enkripsi, hasil dari proses Enkripsinya adalah Oagkp]l maka akan dilakukan proses Deskripsi untuk mengetahui isi sebenarnya dari pesan tersebut, untuk lebih jelasnya dapat dilihat pada Tabel 5 
Tabel 5. Proses Deskripsi

\begin{tabular}{|c|l|}
\hline Karakter & \multicolumn{1}{|c|}{ Proses Deksripsi } \\
\hline O & $\begin{array}{l}\text { Karakter O diubah menjadi ASCII yaitu 79 kemudian dibagi 2, maka } \\
\text { hasilnya lebih 1 (gajil) maka 79+4=83 kemudian hasil penjumlahannya } \\
\text { diubah menjadi karakter yaitu karakter S }\end{array}$ \\
\hline $\mathrm{A}$ & $\begin{array}{l}\text { Karakter a diubah menjadi ASCII yaitu kemudian dibagi 2, maka hasilnya } \\
\text { lebih 1 (gajil) maka 97+4=101 kemudian hasil penjumlahannya diubah } \\
\text { menjadi karakter yaitu karakter e }\end{array}$ \\
\hline $\mathrm{G}$ & $\begin{array}{l}\text { Karakter g diubah menjadi ASCII yaitu 103 kemudian dibagi 2, maka } \\
\text { hasilnya lebih 1 (gajil) maka 103+4=107 kemudian hasil penjumlahannya } \\
\text { diubah menjadi karakter yaitu karakter k }\end{array}$ \\
\hline $\mathrm{K}$ & $\begin{array}{l}\text { Karakter k diubah menjadi ASCII yaitu 107 kemudian dibagi 2, maka } \\
\text { hasilnya lebih 1 (gajil) maka 107+4=111 kemudian hasil penjumlahannya } \\
\text { diubah menjadi karakter yaitu karakter o }\end{array}$ \\
\hline $\mathrm{P}$ & $\begin{array}{l}\text { Karakter p diubah menjadi ASCII yaitu 112 kemudian dibagi 2, maka } \\
\text { hasilnya 0 (genap) maka 112-4=108 kemudian hasil pengurangannya } \\
\text { diubah menjadi karakter yaitu karakter l }\end{array}$ \\
\hline I & $\begin{array}{l}\text { Karakter ] diubah menjadi ASCII yaitu 93 kemudian dibagi 2, maka } \\
\text { hasilnya lebih 1 (gajil) maka 93+4=97 kemudian hasil penjumlahannya } \\
\text { diubah menjadi karakter yaitu karakter a }\end{array}$ \\
\hline L & $\begin{array}{l}\text { Karakter I diubah menjadi ASCII yaitu 108 kemudian dibagi 2, maka } \\
\text { hasilnya 0 (genap) maka 108-4=104 kemudian hasil pengurangannya } \\
\text { diubah menjadi karakter yaitu karakter h }\end{array}$ \\
\hline
\end{tabular}

\section{Kesimpulan}

Berdasarkan hasil pengujian yang dilakukan dalam penelitian ini, dapat disimpulkan bahwa :

1. Huruf, angka, atau simbol dapat diubah menggunakan proses enkripsi menggunakan perangkat lunak hasil rancangan, menjadi huruf, angka, atau simbol lainnya sehingga tidak mudah dimengerti orang lain, dan dikembalikan kebentuk aslinya menggunakan proses deskripsi sehingga hasilnya dapat dibaca.

2. Pengujian Algoritma Lipat yang digunakan untuk proses enkripsi dan deskripsi menggunakan perangkat lunak hasil rancangan dapat mengamankan pesan berupa kata ataupun kalimat yang sampai dengan 2.305 karakter.

\section{Daftar Pustaka}

[1] Assaidi, A. S., \& Amborowati, A. (2016). Perancangan Aplikasi Diary Menggunakan Algoritma Kriptografi RC6 Berbasis Android. SEMNASTEKNOMEDIA ONLINE, 4(1), 4-7. 
[2] Basuki, A., Paranita, U., \& Hidayat, R. (2016). Perancangan Aplikasi Kriptografi Berlapis Menggunakan Algoritma Caesar, Transposisi, Vigenere, Dan Blok Chiper Berbasis Mobile. SEMNASTEKNOMEDIA ONLINE, 4(1), 1-2.

[3] Kurniawan, S. T. C., Dedih, D., \& Supriyadi, S. (2018). Implementasi Kriptografi Algoritma Rivest Shamir Adleman dengan Playfair Cipher pada Pesan Teks Berbasis Android. Jurnal Online Informatika, 2(2), 102-109.

[4] Mangundap, R., \& Kristiana, W. (2015). Aplikasi Secure Message Menggunakan Algoritma Rc6 Berbasis Android. E-Jurnal SPIRIT PRO PATRIA, 1(2).

[5] Muttaqin, M., Sajati, H., \& Retnowati, N. D. (2014). Penerapan Sistem Keamanan Menggunakan Cryptography Pada Aplikasi Chatting Dengan Memodifikasi Algoritma Rivest Shamir Adleman (Rsa). Compiler, 3(1).

[6] Permana, A. A. (2018). Penerapan Kriptografi Pada Teks Pesan dengan Menggunakan Metode Vigenere Cipher Berbasis Android. JURNAL Al-AZHAR INDONESIA SERI SAINS DAN TEKNOLOGI, 4(3), 110-115.

[7] Pratama, G. M., \& Tamatjita, E. N. (2015). Modifikasi Algoritma Vigenère Cipher Menggunakan Metode Catalan Number Dan Double Columnar Transposition. Compiler, 4(1).

[8] Qurniawan, W., Wintolo, H., \& Nugraheny, D. (2012). Penerapan Sistem Keamanan dengan Kriptografi Advanced Encryption Standard (Aes) dan Key Administrator pada Sinkronisasi File. Compiler, 1(2).

[9] Tumalewa, H. T., Andjarwirawan, J., \& Handojo, A. (2013). Pembuatan Aplikasi Penyimpanan Informasi Rahasia pada Mobile Device Android dengan Metode Kriptografi Serpent Cipher. Jurnal Infra, 1(2), pp-146.

[10] Wintolo, H., Retnowati, N. D., \& Fendriyanto, P. (2013, December). Penerapan Alogritma Lipat Pada Steganografi Yang Memanfaatkan Rms (Record Management System) Di J2ME. In Conference SENATIK STT Adisutjipto Yogyakarta (Vol. 1, p. 76). 